\title{
Przepływy ludności związane z zatrudnieniem na przykładzie gminy Uniejów
}

STRESZCZENIE | Dojazdy do pracy stanowią najważniejszy i najlepiej zauważalny przejaw powiązań przestrzenno-funkcjonalnych między poszczególnymi miejscowościami, gminami, powiatami oraz innymi regionami. Z tego powodu podkreśla się istotność ich badania w kontekście dociekań naukowych, ale też na różnych szczeblach planowania przestrzennego. W artykule zidentyfikowano kierunki i skalę dojazdów do pracy w odniesieniu do gminy miejsko-wiejskiej Uniejów. Analizując dane Głównego Urzędu Statystycznego o przemieszczeniach ludności związanych z zatrudnieniem w latach 2006, 20II i 20I6, uwzględniające przepływy powyżej dziewięciu osób, stwierdzono wzrost liczby wyjazdów pracowniczych mieszkańców tej jednostki, jak również przyjazdów do pracy w gminie Uniejów osób zameldowanych poza jej granicami.

SŁOWA KLUCZOWE | dojazdy do pracy, gmina Uniejów, przepływy ludności

\section{Wprowadzenie}

Motywacja podróży stanowi jeden z kluczowych czynników mających wpływ na wybór środka transportu oraz długość i częstotliwość przebywania drogi do jakiegoś miejsca. Z uwagi na istnienie wielu możliwości w zakresie grupowania motywacji podróży i brak uniwersalnego ich usystematyzowania w lite-

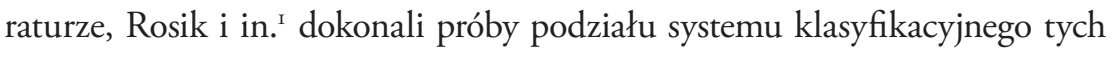
motywacji według obligatoryjności, częstotliwości i długości podróży. Opierając się na powyższych kryteriach, badacze uznali za główne motywacje

\footnotetext{
Paulina Sapińska, mgr, absolwentka, Uniwersytet Łódzki, Wydział Nauk Geograficznych i Wydział Zarządzania; e-mail: paulina95sapinska@gmail.com

I P. Rosik i in., Kompleksowe modelowanie osobowego ruchu drogowego w Polsce. Uwarunkowania na poziomie gminnym, „Prace Geograficzne” 2018, t. 267, s. 95-98.
} 
podróży: wyjazdy na zakupy, dojazdy do pracy, podróże biznesowe, dojazdy do szkoły wyższej, odwiedziny krewnych i znajomych oraz podróże turystyczne. Natomiast do pozostałych zaliczyli motywacje o charakterze sporadycznym, będące na ogół niewielką częścią pracy przewozowej, wykonywanej przez uczestników podróży. Wśród nich wymienili przykładowo przemieszczenia związane z korzystaniem z usług pożytku publicznego i służące rekreacji.

Niniejszy artykuł koncentruje się na aspekcie dojazdów do pracy, które po wyeliminowaniu z ogółu podróży powrotów ludności do domów stanowią najczęściej wybieraną przez Polaków motywację wyruszenia w drogę ${ }^{2}$. Zgodnie z założeniami przyjętymi przez Rosika i in. ${ }^{3}$ dojazdy do pracy są podróżami codziennymi, wykonywanymi w większości w dni powszednie i raczej na krótkich dystansach, liczących poniżej $100 \mathrm{~km}$. Traktuje się je również jako obligatoryjne, co oznacza, że nie można ich odbywać w innym czasie lub miejscu ani całkowicie zrezygnować z ich realizacji, ponieważ determinują one podjęcie obowiązkowych dla człowieka czynnościł. Same „dojazdy”, kojarzone na ogół z koniecznością korzystania ze środków transportu, to w sensie dosłownym systematyczne przemieszczanie się do danego miejsca. Mianem „dojeżdżających” określa się więc ludzi przemieszczających się z jednego punktu do drugiego, przy czym „dojeżdżającymi do pracy” są wszyscy ci, którzy przemieszczają się na trasie dom-praca-dom. W związku z trudnościami w dokonaniu precyzyjnego podziału sposobów dojazdów stosowany w opracowaniach naukowych termin „dojeżdżających do pracy” oznacza osoby przebywające drogę do miejsca pracy zarówno pieszo, jak i przy pomocy różnych środków transportu. Definicje zawarte w literaturze zagranicznej uwzględniają regularność wykonywanych przemieszczeń. Jednocześnie różnią się między sobą w zakresie realizowanego celu, a także dokładnością określenias. W polskich publikacjach grupę osób dojeżdżających do pracy spośród zbiorowości zatrudnionych wyróżniano

2 Badanie pilotażowe zachowań komunikacyjnych ludności w Polsce, etap III - raport końcowy, praca badawcza w ramach projektu: Wsparcie systemu monitorowania polityki spójności w perspektywie finansowej 2007-2013 oraz programowania i monitorowania polityki spójności w perspektywie finansowej 20I4-2020, GUS w Warszawie i Centrum Badań i Edukacji Statystycznej GUS w Jachrance, 20I5, s. 38-39.

3 P. Rosik i in., Kompleksowe modelowanie..., s. 96.

4 K. Hebel, Podróże obligatoryjne mieszkańców polskich miast na przykładzie Gdyni, „Zeszyty Naukowe Uniwersytetu Gdańskiego. Ekonomika Transportu i Logistyka” 20I4, nr 52, s. I29-I45.

5 R. Wiśniewski, Społeczno-demograficzne uwarunkowania dojazdów do pracy do Biategostoku, „Prace Geograficzne” 2013, t. 244, s. 32. 
na podstawie rozmaitych kryteriów. Zdaniem M. Olędzkiego ${ }^{6}$ dojeżdżający do pracy to osoby zamieszkujące w odległości od 4 do $5 \mathrm{~km}$ od miejsca zatrudnienia, czyli utrudniającej codzienne pokonywanie tego dystansu o własnych siłach. Według J.Z. Dzieciuchowicza ${ }^{7}$ dojazdami do pracy są przemieszczenia na trasie dom-praca-dom, na długie i krótkie dystanse, mogące odbywać się w obrębie jednej jednostki administracyjnej, jak i między nimi. W świetle wyników badań przeprowadzonych przez T. Komornickiego ${ }^{8}$ wyróżnikiem dojeżdżającego do pracy jest pokonywanie przez tę osobę pewnej drogi, bez względu na przebieg granic administracyjnych, oraz wykorzystane do tej czynności środki transportu. Jednakże najczęściej stosowane przez polskich i zagranicznych badaczy kryterium dojazdów do pracy opiera się na przekroczeniu granic jednostek administracyjnych na trasie do i podczas powrotu z pracy'. Wskazane jest zatem, aby dobór właściwego kryterium dojazdów do miejsc pracy był zależny od sformułowanego celu badania i uwzględniał kluczowe założenia.

Zdaniem B. Bartosiewicza ${ }^{\text {IO }}$ i R. Guzika ${ }^{\text {II }}$ dojazdy do pracy są jedną z najbardziej regularnych oraz najczęstszych form mobilności społeczeństwa. Przemieszczenia te stanowią zarazem najważniejszy i najlepiej zauważalny przejaw powiązań przestrzenno-funkcjonalnych między poszczególnymi miejscowościami, gminami, powiatami oraz innymi regionami. Z tego powodu podkreśla się istotność ich badania w kontekście dociekań naukowych, ale też na różnych szczeblach planowania przestrzennego ${ }^{\mathrm{I} 2}$. Warto podkreślić, że są one zjawiskiem niezwykle trudnym do uchwycenia, gdyż aktualnie obserwuje się wzrost znaczenia wolnych zawodów i telepracy oraz zwiększającą się pulę zajęć związanych z dużą mobilnością pracowników. Jednocześnie brakuje danych i skutecznych narzędzi umożliwiających uchwycenie całości zjawiska ${ }^{13}$.

6 M. Olędzki, Dojazdy do pracy. Zagadnienia społeczno-ekonomiczne na przykładzie rejonu płockiego, Warszawa 1967.

7 J.Z. Dzieciuchowicz, Rozkłady przestrzenne dojazdów do pracy ludności wielkiego miasta (na przykładzie Łodzi), „Studia KPZK” 1979, t. 66, s. I9.

8 T. Komornicki, Przemiany mobilności codziennej Polaków na tle rozwoju motoryzacji, „Prace Geograficzne” 20II, t. 227, s. 82-86.

9 R. Wiśniewski, Społeczno-demograficzne..., s. 33.

Io B. Bartosiewicz, Powiązania społeczne w Łódzkim Obszarze Metropolitalnym, „Studia KPZK" 20I2, t. I47, s. 83-IOI.

II R. Guzik, Dojazdy do pracy w województwie małopolskim 2006-20II, Kraków 20I5, s. 5.

I2 Tamże, s. 5.

I3 B. Bartosiewicz, Powiąania spoteczne..., s. 84. 
Głównym celem artykułu jest identyfikacja skali i kierunków przepływów ludności związanych z zatrudnieniem na przykładzie gminy Uniejów. W odniesieniu do tej jednostki scharakteryzowano wyjazdy i przyjazdy do pracy w latach 2006, 20I i i 2016.

\section{Dotychczasowe badania nad dojazdami do pracy w Polsce i w regionie łódzkim}

Polska literatura dotycząca codziennej mobilności, zwłaszcza w zakresie dojazdów ludności do pracy (które - jak wspomniano wcześniej - stanowią przemieszczenia obligatoryjne), jest znacznie bogatsza w stosunku do piśmiennictwa dotyczącego przemieszczeń fakultatywnych ${ }^{\mathrm{I}}$. Dynamika uprzemysłowienia kraju po II wojnie światowej przyczyniła się do uruchomienia gwałtownych przemieszczeń społeczeństwa, a w następstwie do dużego zainteresowania zagadnieniem dojazdów do pracy. Najwcześniejszym okresem, w którym nastąił rozwój badań nad tą problematyką w literaturze polskiej, był koniec lat 5o. ubiegłego wieku. Umożliwiła go dostępność danych statystycznych gromadzonych w ramach statystyki bieżącej, spisów powszechnych (z lat 1960, 1970, 1978, 1988) i kadrowych (z lat 1964, 1968, 1973, 1977, 1983) oraz rejestrów pracowników dojeżdżających, prowadzonych przez przedsiębiorstwa państwowe ${ }^{15}$. Podczas transformacji systemowo-ustrojowej naukowcy zrezygnowali ze studiów nad przejazdami do miejsc pracy. Zachodzące w kraju zmiany ograniczyły możliwość prowadzenia badań ze względu na utrudniony w dużej mierze dostęp do statystyki. Materiały w zakresie dojazdów do pracy zgromadzone przez Główny Urząd Statystyczny w czasie spisu powszechnego w I988 r. ostatecznie nie zostały szczegółowo opracowane ani opublikowane. Uzyskane dane spisowe w zmieniającej się w ekspresowym tempie sytuacji gospodarczej odnosiły się do innej rzeczywistości, dlatego stały się mało aktualne i tym samym nieprzydatne ${ }^{16}$. Ponadto podmioty gospodarcze rozpoczęły powoływanie się na ochronę danych osobowych i informacji

\footnotetext{
I4 M. Borowska-Stefańska, S. Wiśniewski, Mobilność codzienna osób starszych w Łodzi, Łódź 2019, s. 15 .

Is R. Wiśniewski, Codzienne dojazdy do pracy - metodyczne aspekty badania wielkości i struktury dojazdów na przykładzie Białegostoku, „Studia Regionalne i Lokalne” 20I2, $\mathrm{nr}_{3}$ (49), s. 50-64.

I6 Tamże.
} 
dotyczących ich działalnościci ${ }^{17}$. Od 1989 r. służby statystyki publicznej nie wykazywały szerszego zainteresowania dojazdami do pracy $^{18}$. Brak pytań odnoszących się do powyższego tematu w kwestionariuszu Narodowego Spisu Powszechnego w 2002 r. wpłynął na powstanie dużej luki w wiedzy o tych przemieszczeniach ${ }^{19}$.

Utrzymujący się przez kilkanaście lat deficyt wpłynął na decyzję Urzędu Statystycznego w Poznaniu o podjęciu próby określenia kierunków i natężenia dojazdów do pracy na terenie województwa wielkopolskiego ${ }^{20}$, a w dalszej kolejności dla całego państwa. Opracowanie Głównego Urzędu Statystycznego opublikowane w październiku 20 Io r. i macierz udostępniona w 201 I r. dotyczą przepływów ludności Polski związanych z zatrudnieniem w 2006 r. ${ }^{21}$ Przeprowadzenie tego badania było możliwe dzięki udostępnionym przez Ministerstwo Finansów zbiorom systemu podatkowego urzędów skarbowych, zgromadzonym w bazie POLTAX. Założono wówczas, że dojeżdżający do pracy to podatnicy wykazujący w formularzu podatkowym PIT-II/8B albo PIT-40 za 2006 r., zwiększone koszty uzyskania przychodu z tytułu dojazdów do pracy i jednocześnie mieszkający w gminie innej niż ta, gdzie zlokalizowane jest ich miejsce zatrudnienia ${ }^{22}$. Należy w tym miejscu wskazać na niedoszacowanie dojazdów do miejsc pracy, mające związek z przyjętą metodyką. Kalkulacje Głównego Urzędu Statystycznego uwzględniały jedynie zatrudnionych, a więc pomijały samozatrudnionych, liczących blisko $25 \%$ ogółu pracujących (o tyle należałoby powiększyć zbiorowość dojeżdżających do pracy). Obliczenia wykluczały również osoby, którym pracodawcy nie zwiększali kosztu uzyskania przychodu z tytułu dojazdów (luka rzędu nawet ıo\%). Wypunktowania wymagają też osoby zamieszkujące suburbia i dojeżdżające do pracy do miasta, a zarazem zameldowane w tym mieście, oraz migranci określani wahadłowymi, do których zalicza się populację pracujących na co dzień na terenie

I7 R. Matykowski, A. Tobolska, Funkcjonowanie zakładów przemystowych XXI wieku na przyktadzie Swedwood Poland i Volkswagen Motor Polska Sp. z o.o. Analiza dojazdów do pracy, „Prace Komisji Geografii Przemysłu” 2009, nr I4, s. 65-75.

I8 Dojazdy do pracy w Polsce. Terytorialna identyfikacja przepływów ludności zwiąanych z zatrudnieniem, K. Kruszka (red.), Poznań 2oIo, s. 3.

I9 R. Wiśniewski, Społeczno-demograficzne..., s. 9.

20 Dojazdy do pracy $w$ Polsce ..., s. 3.

2I Tamże.

22 https://stat.gov.pl/cps/rde/xbcr/poznan/ASSETS_Dojazdy_do_pracy_metodologia_do_internetu.pdf [dostęp: I5.04.2021]. 
dużego ośrodka miejskiego, niedojeżdżających do pracy w ciągu tygodnia. Grupy te wyłączono z szacunków z powodu braku różnicy między gminą zakładu pracy a gminą zameldowania. Co więcej, udostępniona macierz dla 2006 r. ukazuje przepływy wyłącznie powyżej dziewięciu osób (stanowiące około 90\% dojazdów do pracy) z uwagi na tajemnicę statystyczną.

Następną edycję badania przeprowadzono w 20I I r. Jego metodyka różniła się jednak nieco od poprzednio przyjętej, ponieważ tym razem bazowano na rejestrze Zakładu Ubezpieczeń Społecznych, a dane z systemu informacji podatkowej POLTAX stanowiły źródło pomocnicze. Zbiory Kasy Rolniczego Ubezpieczenia Społecznego posłużyły do zidentyfikowania rolników indywidualnych, lecz ostatecznie nie objęto ich badaniem. Po drugie, uwzględniono informacje zgromadzone w ramach spisu powszechnego w 201 I r., pozwalające scharakteryzować zbiorowość dojeżdżających do pracy w ujęciu ogólnopolskim oraz na poziomie regionalnym ${ }^{23}$. By możliwe było przeprowadzenie porównania wyników tego badania z danymi o dojazdach pracowniczych z poprzedniej edycji, Główny Urząd Statystyczny w 2014 r. udostępnił macierz przepływów międzygminnych, zawierająca - jak w zestawieniu za 2006 r. - podział gmin miejsko-wiejskich na odrębne części oraz obejmującą zatrudnionych, dla których źródło przychodów stanowiły wynagrodzenia ze stosunku: pracy, służbowego, spółdzielczego i pracy nakładczej, ale też zasiłki pieniężne z ubezpieczenia społecznego wypłacane przez zakład pracy. Identycznie jak w ubiegłym badaniu opublikowana baza danych za 20 I r r. uwzględnia przemieszczenia powyżej dziewięciu osób ${ }^{24}$.

Najnowsze źródło wiedzy o dojazdach do pracy w Polsce pochodzi z końca maja 2019 r. i obejmuje dane za 2016 r. W opracowaniu poświęconym temu badaniu brakuje szczegółowych informacji o etapach postępowania zmierzającego do wygenerowania zbiorowości pracowników najemnych dojeżdżających do pracy poza gminę swojego zamieszkania, co stanowi regres względem lat poprzednich. Publikacja z 2019 r. zawiera jedynie informację o źródłach danych. Były nimi bazy udostępnione przez Ministerstwo Finansów i Zakład Ubezpieczeń Społecznych ${ }^{25}$. Nowością w dotychczasowej praktyce statystyki publicznej jest macierz dostępności opracowana przez

23 Dojazdy do pracy. Narodowy Spis Powszechny Ludności i Mieszkań 20II, Główny Urząd Statystyczny, Warszawa 20I4, s. 27-28.

24 Tamże.

25 Przeptywy ludności związane z zatrudnieniem w 2016 r., Główny Urząd Statystyczny, Warszawa 2019, s. I. 
Urząd Statystyczny w Poznaniu, nawiązująca do badania przepływów ludności związanych z zatrudnieniem w 2016 r. Przy wykorzystaniu danych przestrzennych i atrybutowych, zaczerpniętych z państwowego rejestru granic i powierzchni jednostek podziałów terytorialnych kraju oraz wolnego zasobu baz danych informacji przestrzennej OpenStreetMap (aktualność danych to odpowiednio 2016 r. oraz przełom lat 2016 i 2017), oszacowano odległości geodezyjne i drogowe, a także czas przejazdu samochodem osobowym między gminami. Opublikowano dodatkowo pliki graficzne, przedstawiające obszary o identycznej dostępności czasowej do miast wojewódzkich ${ }^{26}$.

Przegląd literatury poruszającej tematykę dojazdów do pracy umożliwia pogrupowanie opracowań według podejmowanych problemów badawczych. K. Marciniak ${ }^{27}$ wyróżniła publikacje dotyczące dojazdów: wewnątrzmiejskich, do poszczególnych miast, w obrębie aglomeracji bądź ośrodka przemysłowego, na terenach wiejskich, do konkretnych zakładów pracy, jak również wpływu dojazdów do miejsc pracy na jakość życia i metodologiczno-teoretycznych aspektów studiów nad tymi dojazdami. Zdaniem R. Wiśniewskiego ${ }^{28}$ dorobek piśmienniczy w tym zakresie można podzielić, opierając się na skali i charakterze badań, na opracowania poświęcone dojazdom na obszarze całego kraju, danego regionu lub do poszczególnych ośrodków miejskich, do konkretnego zakładu pracy oraz dotyczące teoretycznego i metodycznego ujęcia dojazdów do pracy. Oprócz wcześniej wymienionych badaczy autorzy najważniejszych publikacji tematycznie związanych z przemieszczeniami pracowniczymi to: J. Herma ${ }^{29}$, A. Jagielski ${ }^{30}$, J. Cegielski ${ }^{31}$, J. Namy-

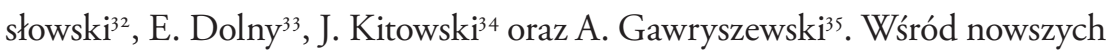

26 https://stat.gov.pl/statystyki-eksperymentalne/obszary-funkcjonalne-oraz-dostepnosc-tery torialna/oszacowanie-odleglosci-i-czasu-przejazdu-pomiedzy-wybranymi-gminami-w-polsce-w-20I6-roku,II,I.html [dostęp: I5.04.202I].

27 K. Marciniak, Dojazdy do pracy i ich uwarunkowania na terenach wiejskich powiatu kutnowskiego, rozprawa doktorska, Uniwersytet Łódzki, Łódź 2019, s. 37-38.

28 R. Wiśniewski, Społeczno-demograficzne..., s. 36.

29 J. Herma, Dojazdy do pracy w Polsce Południowej (województwo katowickie, kieleckie, krakowskie, opolskie, rzeszowskie) 1958-1961, Kraków 1966.

30 A. Jagielski, Niektóre przestrzenne aspekty dojazdów do pracy, „Przegląd Geograficzny” I969, t. 4I, s. 65I-672.

3I J. Cegielski, Problemy dojazdów do pracy. Próba syntezy, Warszawa 1977.

32 J. Namysłowski, Główne ośrodki codziennych dojazdów i wyjazdów w Polsce, Toruń I980.

33 E. Dolny, Społeczno-ekonomiczne problemy dojazdów do pracy, Toruń 1983.

34 J. Kitowski, Rola dojazdów do pracy w gospodarce narodowej, Lublin 1988.

35 A. Gawryszewski, Przestrzenna ruchliwość ludności Polski 1952-1985, Prace habilitacyjne IGiPZ PAN, Warszawa 1989. 
pozycji na uwagę zasługują opracowania autorstwa: P. Rosika i in. ${ }^{36}$, R. Bula ${ }^{37}$, T. Komornickiego ${ }^{38}$, S. Kurka i in..$^{39}$, M. Paneckiej-Niepsuj ${ }^{40}$, M. Borowskiej-Stefańskiej i in. ${ }^{41}$ oraz R. Guzika i in. ${ }^{42}$

Mimo wielu publikacji o dojazdach ludności do pracy, znajomość tej tematyki w odniesieniu do regionu łódzkiego jest niewielka43. Spośród prac poruszających to zagadnienie należy wymienić opracowanie L. Straszewicza ${ }^{44}$, który opisał dojazdy i rozmieszczenie miejsc pracy i zamieszkania na terenie Łódzkiego Okręgu Przemysłowego. H. Mortimer-Szymczak ${ }^{45}$ scharakteryzowała dojazdy ludności zamiejscowej do pracy w Łodzi. J.Z. Dzieciuchowicz ${ }^{46}$ dokonał analizy wewnątrzmiejskich dojazdów pracowniczych na przykładzie Łodzi. B. Bartosiewicz ${ }^{47}$ poruszył kwestię dojazdów do pracy w ramach Łódzkiego Obszaru Metropolitalnego, natomiast badania M. Borowskiej-Stefańskiej i S. Wiśniewskiego ${ }^{48}$ oraz M. Borowskiej Stefańskiej i in. ${ }^{49}$ miały na celu zidentyfikowanie cech mobilności przestrzennej osób powyżej 6o. roku życia, zamieszkujących dwie z dzielnic Łodzi (odpowiednio Śródmieście i Bałuty)

36 P. Rosik i in., Dojazdy do pracy do Warszawy i Białegostoku - alternatywne podejścia metodologiczne, „Studia Regionalne i Lokalne” 20Io, nr 2 (40), s. 77-98.

37 R. Bul, Dojazdy do pracy w aglomeracji poznańskiej i województwie wielkopolskim w 2016 roku, „Prace Komisji Geografii Komunikacji PTG” 20I9, nr 22 (4), s. 75-94.

38 T. Komornicki, Przemiany mobilności..., s. 82-86.

39 S. Kurek i in., Powiazania funkcjonalno-przestrzenne w Krakowskim Obszarze Metropolitalnym w świetle dojazdów do pracy, „Studia Miejskie” 20I5, nr I8, s. 7I-84.

40 M. Panecka-Niepsuj, Przestrzenne zróżnicowanie miast średniej wielkości w Polsce wg dojazdów do pracy, „Annales Universitatis Paedagogicae Cracoviensis. Studia Geographica” 20I5, nr 9, s. 83-95.

4I M. Borowska-Stefańska i in., Changes in travel time and the load of road network, depending on the diversification of working hours: case study the Eódz Voivodeship, Poland, „Geografie” 2020, nr I25 (2), s. 2II-24I.

42 R. Guzik i in., Dostępność komunikacyjna i relacje przestrzenne w województwie pomorskim, Kraków 2020.

43 J.Z. Dzieciuchowicz, Rozktady przestrzenne..., s. I6.

44 L. Straszewicz, Rozmieszczenie miejsc pracy i zamieszkania w Łódzkim Okręgu Przemystowym, „Przegląd Geograficzny” 1956, t. 28, z. 4, s. 775-794.

45 H. Mortimer-Szymczak, Uwagi w sprawie dojazdów do pracy, „Łódzkie Czasopismo Gospodarcze” 196I, nr 9, s. 2I-36.

46 J.Z. Dzieciuchowicz, Rozktady przestrzenne..., s. 8.

47 B. Bartosiewicz, Powiazania spoteczne..., s. 83.

48 M. Borowska-Stefańska, S. Wiśniewski, Mobilność codzienna..., s. 8.

49 M. Borowska-Stefańska i in., Daily mobility of the elderly: An Example from Łódź, Poland, „Acta Geographica Slovenica” 2020, nr 60 (2), s. 57-70. 
i uwzględniały między innymi przemieszczenia tej grupy mieszkańców miasta do pracy. Warto w tym miejscu wspomnieć również o rozprawie doktorskiej K. Marciniak ${ }^{\text {so }}$, której przedmiotem były dojazdy do pracy na obszarach wiejskich w powiecie kutnowskim.

\section{Przedmiot analiz i metodologia}

Gmina Uniejów to jednostka o charakterze miejsko-wiejskim, położona nad brzegiem rzeki Warty, w północno-zachodniej części powiatu poddębickiego i jednocześnie województwa łódzkiego. Według stanu z końca 2019 r. zamieszkiwało ją nieco ponad 7 tys. osób, z czego 3 tys. stanowili mieszkańcy obszaru miasta ${ }^{51}$. Jej wybór jako przedmiotu analiz był podyktowany zamiarem uzupełnienia dorobku literatury podejmującej tematykę dojazdów do miejsc pracy o opracowanie dotyczące jednostki, która do niedawna obsługiwała jedynie najbliższe zaplecze, a dzięki rozwojowi funkcji wypoczynkowo-uzdrowiskowej stała się zauważalna w regionie, jak i na tle całego kraju ${ }^{{ }^{2}}$.

Za źródło informacji wykorzystanych do zbadania skali i kierunków przemieszczeń związanych z zatrudnieniem z i do gminy Uniejów posłużyły wspomniane wcześniej trzy macierze, pobrane ze strony internetowej Głównego Urzędu Statystycznego ${ }^{53}$. Każda z nich wymagała zredukowania danych do uzyskania wyłącznie par gmin, w których gmina Uniejów stanowiła gminę zamieszkania lub gminę pracy. Użyto do tego narzędzia filtrowania w programie Microsoft Excel 20I6. Prócz analizy macierzy przepływów zastosowano kartograficzną metodę prezentacji w postaci kartodiagramów wstęgowych. W celu zobrazowania zjawiska zaczerpnięto dane z państwowego rejestru granic i powierzchni jednostek podziałów terytorialnych kraju, dostępne na witrynie internetowej Głównego Urzędu Geodezji i Kartografiił ${ }^{\lessgtr 4}$. Opracowania kartograficzne wykonano przy użyciu oprogramowania ArcGIS wersji Io.4.I. Artykuł zawiera także zestawienia tabelaryczne.

50 K. Marciniak, Dojazdy do pracy i ich uwarunkowania..., s. 8.

5I https://bdl.stat.gov.pl/BDL/dane/teryt/tablica [dostęp: 15.04.202I].

52 M. Lamprecht, Kilka uwag o rozwoju Uniejowa w świetle nowych funkcji miasta, „Biuletyn Uniejowski” 20I2, t. I, s. I3I-I40.

53 https://stat.gov.pl/ [dostęp: 15.04.202I].

54 http://www.gugik.gov.pl/pzgik/dane-bez-oplat/dane-z-panstwowego-rejestru-granic-i-powierzchni-jednostek-podzialow-tery torialnych-kraju-prg [dostęp: 15.04.202I]. 
Z uwagi na uwzględnienie przez Główny Urząd Statystyczny w badaniach dojazdów do pracy relacji zachodzących między miastem i obszarem wiejskim we wszystkich gminach mieszanych oraz traktowanie tych części gmin jako samoistnych jednostek terytorialnych, w kontekście niniejszych rozważań również przyjęto, że miasto Uniejów i obszar wiejski gminy to odrębne jednostki. Słowa „gmina” w nagłówkach tabel użyto jedynie dla uproszczenia zapisu. Podział gmin miejsko-wiejskich na dwie części został pominięty na kartodiagramach wstęgowych w celu polepszenia czytelności map.

\section{Wyniki}

Jak wskazują dane statystyczne, w 2006 r. mieszkańcy gminy Uniejów dojeżdżali do pracy głównie do trzech miast: Łodzi, Poddębic i Turku. Najmniejsze przepływy odbywały się w kierunku gminy Świnice Warckie (tab. I). Biorąc pod uwagę wewnątrzgminne przemieszczenia pracownicze w gminie objętej opracowaniem, można zaobserwować ponad sześciokrotnie większą liczbę osób dojeżdżających z obszarów wiejskich gminy Uniejów do Uniejowa w porównaniu do zbiorowości zamieszkującej miasto Uniejów i pracującej w wiejskiej części analizowanej jednostki.

Podkreślenia wymaga fakt, że nie odnotowano wówczas przyjazdów do gminy Uniejów ludności spoza jej granic. Należy jednak pamiętać o wykluczeniu ze statystyk potoków liczących poniżej Io osób.

Z przeprowadzonych analiz macierzy przepływów ludności związanych z zatrudnieniem wynika, że w 201 I r. zasięg wyjazdów pracowniczych z gminy Uniejów rozszerzył się na województwo mazowieckie (ryc. I), ponieważ po I I osób z Uniejowa i z obszarów wiejskich analizowanej gminy dojeżdżało do pracy do Warszawy. Wśród mieszkańców Uniejowa nowymi kierunkami wyjazdów do pracy stały się gminy Wartkowice i Świnice Warckie. Z kolei dla osób zamieszkujących obszary wiejskie gminy Uniejów atrakcyjnym miejscem pracy zaczęło być miasto Koło. W przemieszczeniach międzywojewódzkich można dostrzec dominującą pozycję Turku. Największą skalą dojazdów do pracy wśród mieszkańców gminy Uniejów cechowała się stolica województwa łódzkiego. Zważywszy na sumę osób wyjeżdżających z każdej z części gminy Uniejów do pracy, w przypadku miasta przepływy zwiększyły się o około 29,I\% w stosunku do 2006 r. Wyjazdy z obszarów wiejskich wzrosły natomiast o 50,3\%, przy czym aż 28,9\% ogólnej ich liczby odbywało się wówczas do Uniejowa. 
Tabela I. Liczba osób wyjeżdżających z gminy Uniejów do pracy w latach 2006, 20II i 2016

\begin{tabular}{|c|c|c|c|c|}
\hline \multirow[t]{2}{*}{ Gmina zamieszkania } & \multirow[t]{2}{*}{ Gmina pracy } & \multicolumn{3}{|c|}{$\begin{array}{l}\text { Liczba osób wyjeżdżających } \\
\text { do pracy w latach }\end{array}$} \\
\hline & & 2006 & $2 \mathrm{OII}$ & 2016 \\
\hline \multirow{9}{*}{ 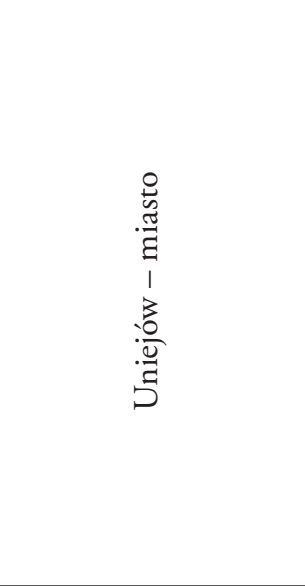 } & Łódź & 50 & 60 & 68 \\
\hline & m.st. Warszawa & - & II & - \\
\hline & $\begin{array}{l}\text { Poddębice - } \\
\text { miasto }\end{array}$ & 58 & 52 & 39 \\
\hline & Przykona & - & - & 15 \\
\hline & Świnice Warckie & - & I3 & - \\
\hline & Turek - miasto & 47 & 47 & 30 \\
\hline & $\begin{array}{l}\text { Uniejów - obszar } \\
\text { wiejski }\end{array}$ & IO & I3 & 29 \\
\hline & Warta - miasto & - & - & I6 \\
\hline & Wartkowice & - & 17 & I4 \\
\hline \multicolumn{2}{|c|}{$\begin{array}{l}\text { Suma osób wyjeżdżających } \\
\text { do pracy w danym roku }\end{array}$} & 165 & $2 \mathrm{I} 3$ & $2 \mathrm{II}$ \\
\hline \multirow{10}{*}{ 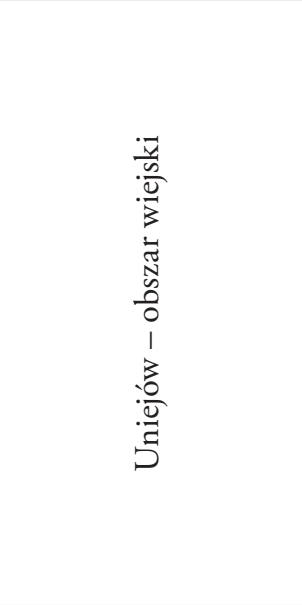 } & Dąbie - miasto & - & - & II \\
\hline & Koło - miasto & - & $\mathrm{I} 3$ & I8 \\
\hline & Łódź & 46 & 67 & 89 \\
\hline & m.st. Warszawa & - & II & 20 \\
\hline & $\begin{array}{l}\text { Poddębice - } \\
\text { miasto }\end{array}$ & 25 & 28 & 29 \\
\hline & Świnice Warckie & $\mathrm{I} 2$ & 24 & IO \\
\hline & Turek - miasto & $3 \mathrm{I}$ & 44 & 26 \\
\hline & Uniejów - miasto & 6I & 76 & $\mathrm{I} 30$ \\
\hline & Warta - miasto & - & - & $\mathrm{I} 2$ \\
\hline & Wartkowice & - & - & I8 \\
\hline \multicolumn{2}{|c|}{$\begin{array}{l}\text { Suma osób wyjeżdżających } \\
\text { do pracy w danym roku }\end{array}$} & I75 & 263 & 363 \\
\hline
\end{tabular}

Źródło: opracowanie własne na podstawie danych Głównego Urzędu Statystycznego 


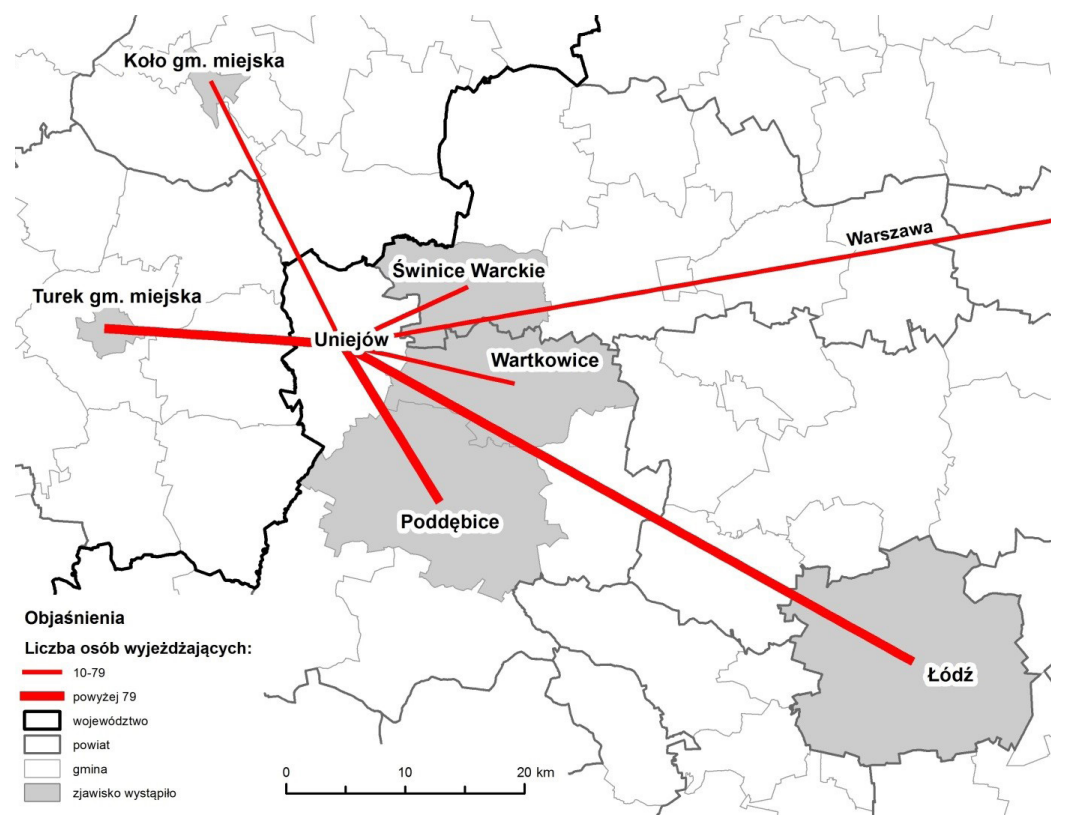

Ryc. I. Skala i kierunki wyjazdów do pracy z gminy Uniejów w 20 I r r.

Źródło: opracowanie własne na podstawie danych Głównego Urzędu Statystycznego

Wyliczenia Głównego Urzędu Statystycznego wskazują na intensyfikację przyjazdów ludności do pracy w gminie Uniejów w 20I I r. względem wyników poprzedniej edycji badania (tab. 2). Dotyczyła ona jednak wyłącznie miasta Uniejów, będącego celem przyjazdów pracowniczych mieszkańców gminy Wartkowice i osób zamieszkujących wiejską część gminy Poddębice. Mimo to można przypuszczać, że w Uniejowie, w związku z podejmowanymi staraniami samorządu o nadanie miastu statusu uzdrowiska, powiększyła się wtedy liczba miejsc pracy, co skutkowało wchłonięciem lokalnych zasobów.

Po porównaniu ogólnej liczby wyjeżdżających z analizowanej jednostki do pracy w latach 20II i 20I6, nasuwa się wniosek, że wzrosła ona o 20,6\%. Mając na uwadze dojazdy pracownicze mieszkańców miasta, suma ta niezauważalnie zmalała, a w przypadku mieszkańców obszarów wiejskich gminy Uniejów zwiększyła się o 38\%. Zupełnie nowy kierunek przepływów ludności związanych z zatrudnieniem w $2016 \mathrm{r}$. to powiat sieradzki, a konkretnie miasto Warta (ryc. 2). Względem 201 I r. zasięg wyjazdów mieszkańców jednostki objętej badaniem w 2016 r. rozszerzył się ponadto na sąsiadującą z nią od strony zachodniej gminę Przykona oraz miasto Dąbie. Identycznie 
Tabela 2. Liczba osób przyjeżdżających do pracy do gminy Uniejów w latach 2006, 20 I i 2016

\begin{tabular}{|c|c|c|c|c|}
\hline \multirow[t]{2}{*}{ Gmina zamieszkania } & \multirow{2}{*}{$\begin{array}{c}\text { Gmina } \\
\text { pracy }\end{array}$} & \multicolumn{3}{|c|}{$\begin{array}{l}\text { Liczba osób przyjeżdżających } \\
\text { do pracy w latach }\end{array}$} \\
\hline & & 2006 & $2 \mathrm{OII}$ & 2016 \\
\hline Dąbie - obszar wiejski & \multirow{7}{*}{ 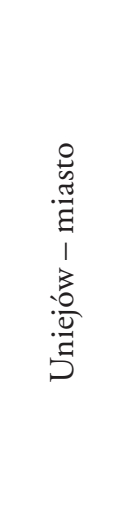 } & - & - & II \\
\hline Łódź & & - & - & $\mathrm{I} 2$ \\
\hline Poddębice - miasto & & - & - & I7 \\
\hline Poddębice - obszar wiejski & & - & $2 \mathrm{I}$ & 33 \\
\hline Świnice Warckie & & - & - & $\mathrm{I} 2$ \\
\hline Uniejów - obszar wiejski & & 6I & 76 & I3O \\
\hline Wartkowice & & - & 15 & 29 \\
\hline \multicolumn{2}{|c|}{$\begin{array}{l}\text { Suma osób przyjeżdżających } \\
\text { do pracy w danym roku }\end{array}$} & 6I & II2 & 244 \\
\hline Łódź & \multirow{3}{*}{ 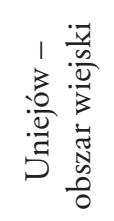 } & - & - & $\mathrm{I} 2$ \\
\hline Uniejów - miasto & & IO & $\mathrm{I} 3$ & 29 \\
\hline Wartkowice & & - & - & $2 \mathrm{I}$ \\
\hline \multicolumn{2}{|c|}{$\begin{array}{c}\text { Suma osób przyjeżdżających } \\
\text { do pracy w danym roku }\end{array}$} & IO & $\mathrm{I} 3$ & 62 \\
\hline
\end{tabular}

Źródło: opracowanie własne na podstawie danych Głównego Urzędu Statystycznego

jak poprzednio w 2016 r. Łódź była ośrodkiem koncentrującym najwięcej osób wyjeżdżających do pracy z gminy Uniejów. Tym razem dojeżdżało do niej jednak o 23,6\% więcej mieszkańców jednostki objętej analizą niż w 20 I I r. Z zestawienia obejmującego przepływy pracowników najemnych w 2016 r. wynika, że liczące powyżej dziewięciu osób grupy uniejowian nie dojeżdżały już do pracy do Warszawy i gminy Świnice Warckie, podczas gdy mieszkańcy obszarów wiejskich gminy Uniejów, prócz do Uniejowa, wyjeżdżali pracować do łącznie dziewięciu jednostek (w tym pięciu graniczących bezpośrednio z gminą ich zameldowania). Interesującą kwestią jest 
sytuacja dotycząca jednostek podziału terytorialnego, dla których odnotowano spadek przyjezdnych z gminy Uniejów. Mniejsze grupy uniejowian dojeżdżały do miast Poddębice i Turek oraz do gminy Wartkowice (spadki wynoszące 17,6-36,2\%). W przypadku osób zamieszkujących wiejską część gminy Uniejów tendencja spadkowa wystąpiła względem Turku i gminy Świnice Warckie (spadki rzędu 40,9-58,3\%).

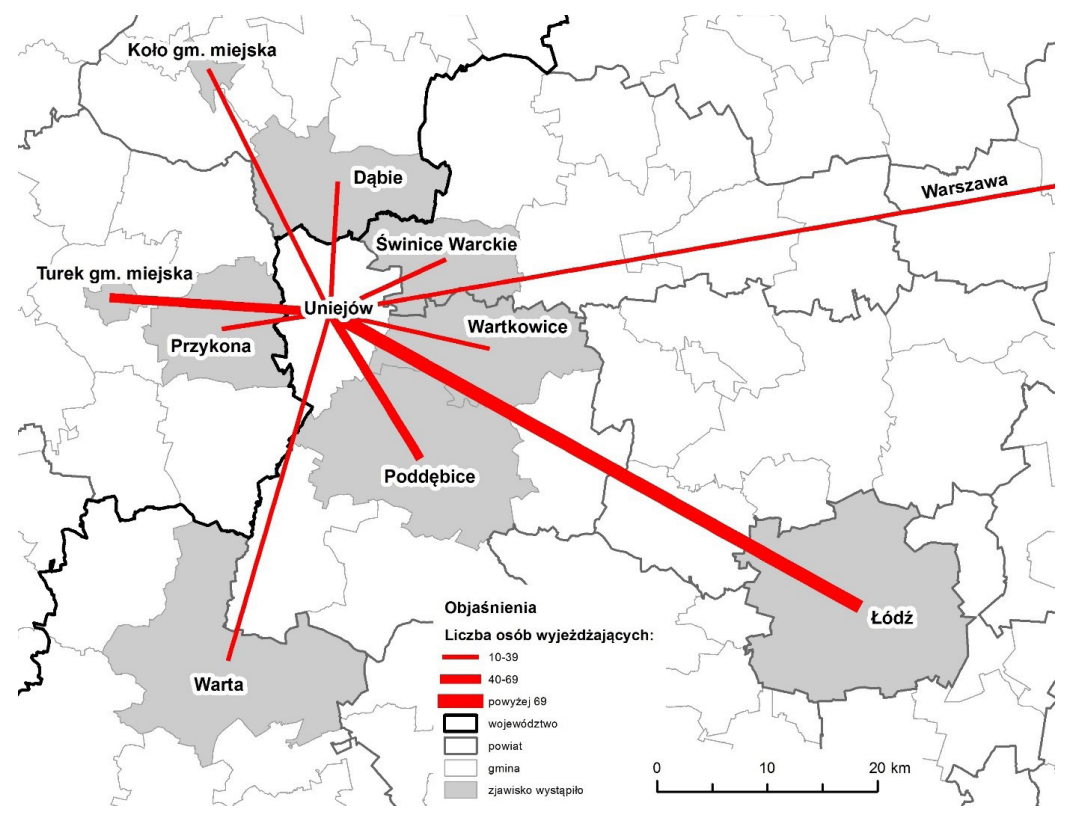

Ryc. 2. Skala i kierunki wyjazdów do pracy z gminy Uniejów w 2016 r.

Źródło: opracowanie własne na podstawie danych Głównego Urzędu Statystycznego

W stosunku do dwóch poprzednich edycji badania dojazdów w celach zarobkowych w 2016 r. dostrzeżono większą atrakcyjność gminy Uniejów jako miejsca pracy, czego dowodem są niewystępujące dotąd przyjazdy pracownicze mieszkańców: Łodzi, miejskiej części gminy Poddębice, gminy Świnice Warckie oraz obszarów wiejskich gminy Dąbie. Najliczniejsze grupy przyjeżdżających stanowili zameldowani w gminach Poddębice i Wartkowice (ryc. 3). Skala dojazdów do pracy do Uniejowa w 2016 r. była większa o II7,9\% w porównaniu do $201 \mathrm{I}$ r. W przypadku obszarów wiejskich jednostki objętej analizą liczba przyjazdów wzrosła aż o $376,9 \%$. 


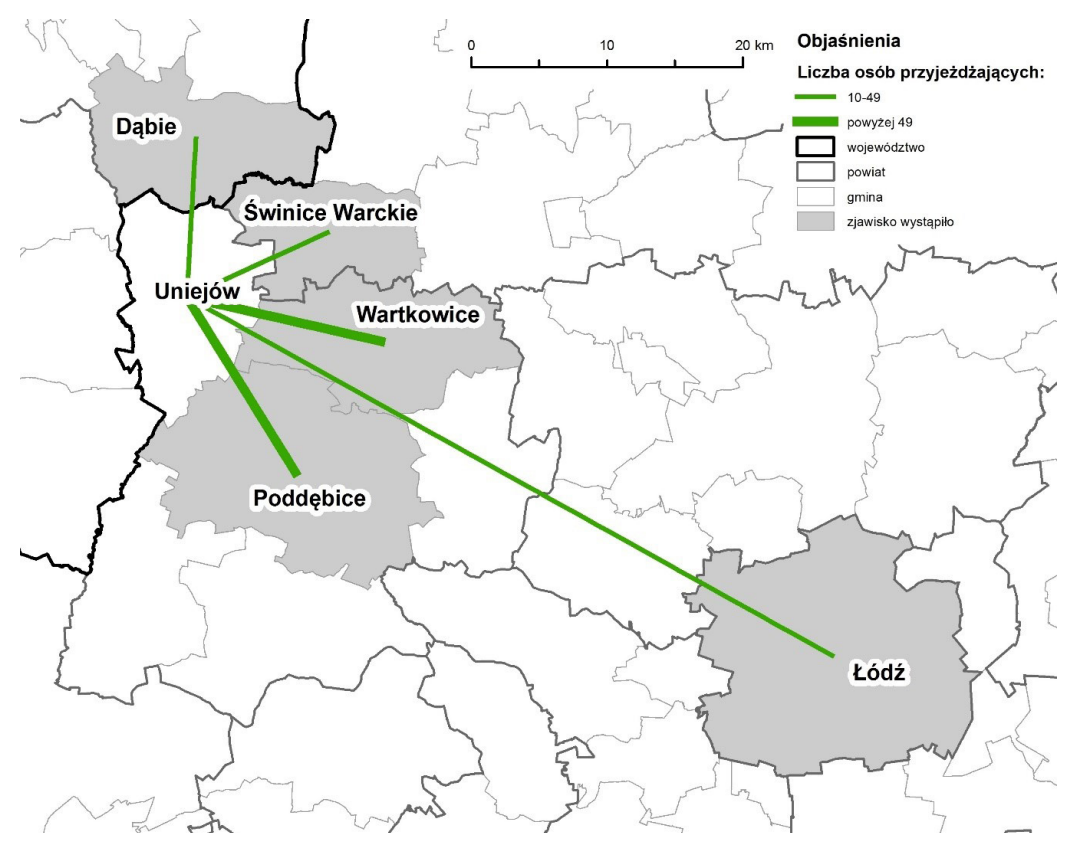

Ryc. 3. Skala i kierunki przyjazdów do pracy do gminy Uniejów w 2016 r.

Źródło: opracowanie własne na podstawie danych Głównego Urzędu Statystycznego

\section{Dyskusja i wnioski}

Ogólnie rzecz biorąc, wyniki badania dojazdów do pracy w 2006 r. nie są stuprocentowo porównywalne i kompatybilne z wynikami kolejnych edycji. Z informacji uzyskanych od Urzędu Statystycznego w Poznaniu wynika, że każdorazowo jako zbiorowość dojeżdżających do pracy traktowano pracowników najemnych, mieszkających w gminie innej niż gmina, w której znajdowało się ich miejsce pracy, jak również mających zwiększone koszty uzyskania przychodu z tytułu dojazdów do pracy. Jednocześnie wskazane wyżej różnice odnoszące się do źródeł danych sprawiają, że każda macierz przepływów ukazuje zjawisko w danym roku i porównania między latami 2006, 201 I i 2016 powinny być prowadzone z rozwagą 5 . Reasumując, zbiory danych o dojazdach do pracy z powyższych trzech okresów to najlepsze i jedyne, jakie są dostępne. Dopuszczalne jest więc ich porównywanie.

W wyniku przeprowadzonego badania udało się zidentyfikować kierunki i skalę dojazdów do pracy w odniesieniu do gminy miejsko-wiejskiej

55 Dojazdy do pracy. Narodowy Spis..., s. I80. 
Uniejów. Zestawiając dane dotyczące przemieszczeń ludności związanych z zatrudnieniem, uwzględniające przepływy powyżej dziewięciu osób, stwierdzono wzrost liczby wyjazdów pracowniczych mieszkańców tej jednostki, jak również przyjazdów do pracy w gminie Uniejów osób zameldowanych poza jej granicami. W 2006 r. większość lokalnej społeczności dojeżdżała do pracy, nie przekraczając przy tym granic województwa łódzkiego, a pozostali $(22,9 \%)$ byli zatrudnieni w województwie wielkopolskim. W latach 201 I i 2016 zakres wyjazdów pracowniczych objął także województwo mazowieckie. Biorąc pod uwagę potoki międzypowiatowe, pierwsza edycja badania ukazała przemieszczenia mieszkańców gminy Uniejów do pracy w granicach powiatu zameldowania, do powiatów tureckiego i łęczyckiego oraz do Łodzi. W kolejnych latach zaobserwowano ponadto dojazdy do miejsc zatrudnienia do powiatów kolskiego i sieradzkiego oraz stolicy kraju. Mając na względzie przemieszczenia związane $\mathrm{z}$ wykonywaniem działalności zarobkowej $\mathrm{w}$ gminie Uniejów, w 2006 r. i 201 I r. nie odnotowano przyjezdnych spoza powiatu poddębickiego. Dopiero w 2016 r. pojawiły się osoby przyjeżdżające do pracy (w gminie Uniejów) z Łodzi i z jednej gminy powiatu kolskiego oraz łęczyckiego.

Dojazdy pracownicze mieszkańców gminy Uniejów do innych powiatów i województw mogą świadczyć o chęci tej zbiorowości do podejmowania pracy w innym regionie, nawet kosztem pokonywania nierzadko większych dystansów, ale też o mobilności siły roboczej. Sama gotowość pracowników poszczególnych przedsiębiorstw do codziennego dojeżdżania do pracy poza miejscowość lub gminę zameldowania niewątpliwie zwiększa się przy wzroście ich poziomu wykształcenia czy kompetencji zawodowych. Międzywojewódzkie przepływy mogą sygnalizować jednocześnie lokalny niedobór miejsc pracy, lecz w przypadku gminy Uniejów wyjazdy te, szczególnie do województwa wielkopolskiego, wynikają z jej położenia. Zgodnie z wyliczeniami (uwzględniającymi przepływy powyżej dziewięciu osób) w każdym z badanych okresów odsetek osób zameldowanych na obszarach wiejskich jednostki, wyjeżdżających do pracy w miastach, wynosił średnio około 92,I\%. Za przyczynę tak wysokiej skali zjawiska należy uznać przemiany funkcjonalne terenów wiejskich, gdzie w wyniku postępującej mechanizacji rolnictwa zmniejsza się zapotrzebowanie na pracowników. Na rosnącą liczbę przepływów pracowniczych wpływ miało także nadanie miastu Uniejów statusu uzdrowiska 
w 2012 r., skutkujące między innymi rozwojem przedsiębiorczości ${ }^{56}$ i stanowiące przełom w zakresie rozpoznawalności tego ośrodka na tle kraju ${ }^{57}$. Wzrosło wówczas zapotrzebowanie między innymi na świadczenie usług towarzyszących działalności turystycznej. Ponadto nie można zapominać o lepszej dostępności drogowej charakteryzowanej gminy, będącej efektem realizacji inwestycji infrastrukturalnych, oraz o poprawie jakości i zakresu funkcjonowania transportu publicznego.

Przemieszczenia ludności do pracy są bez wątpienia wyznacznikiem powiązań przestrzenno-funkcjonalnych, ale i miernikiem wielkości potencjału ekonomicznego poszczególnych jednostek. Mają wpływ na równoważenie rynku pracy z obszarów o mniejszej podaży miejsc pracy do takich, gdzie jest ona większa. Zważywszy na tendencje występowania zjawiska względem poszczególnych jednostek lub ich części oraz zmniejszającą się stopę bezrobocia rejestrowanego mieszkańców gminy Uniejów i zwiększającą się wartość wskaźnika motoryzacji w powiecie poddębickim, można domniemywać, że skala wyjazdów z gminy Uniejów na ogół będzie rosła, a ich zasięg rozszerzać się na kolejne gminy, powiaty, a nawet województwa. Najprawdopodobniej widoczny będzie również trend zwyżkowy przyjezdnych. Kolejne informacje dotyczące przepływów ludności związanych z zatrudnieniem będą jednak dostępne dopiero po zebraniu danych podczas spisu powszechnego w $202 \mathrm{I}$ r.

\section{Bibliografia}

Badanie pilotażowe zachowań komunikacyjnych ludności w Polsce, etap III - raport końcowy, praca badawcza w ramach projektu: Wsparcie systemu monitorowania polityki spójności w perspektywie finansowej 2007-2013 oraz programowania i monitorowania polityki spójności w perspektywie finansowej 20I4-2020, GUS w Warszawie i Centrum Badań i Edukacji Statystycznej GUS w Jachrance, 20I5.

Bartosiewicz B., Powiązania społeczne w Łódzkim Obszarze Metropolitalnym, „Studia KPZK” 2OI2, t. I47, s. 83-IOI.

56 K. Krysiak, Wptyw inwestycji i ustug turystycznych na rozwój przedsiębiorczości w gminie Uniejów, „Biuletyn Uniejowski” 2019, t. 8, s. 99-II4.

57 P. Kurzyk, M. Kowalski, Popularność Uniejowa na tle małych miast regionu łódzkiego oraz konkurujących z nim uzdrowisk, „Biuletyn Uniejowski” 2019, t. 8, s. 77-97. 
Borowska-Stefańska M., Kowalski M., Wiśniewski S., Changes in travel time and the load of road network, depending on the diversification of working hours: case study the Eódź Voivodeship, Poland, „Geografie” 2020, t. I25 (2), s. 2II-24I. https://doi.org/IO.37040/geografie2020I250202II

Borowska-Stefańska M., Kowalski M., Wiśniewski S., Daily mobility of the elderly: An Example from Eódź, Poland, „Acta Geographica Slovenica” 2020, nr 60 (2), s. 57-70. https://doi.org/Io.3986/AGS.7490

Borowska-Stefańska M., Wiśniewski S., Mobilność codzienna osób starszych $w$ Łodzi, Łódź 2019.

Bul R., Dojazdy do pracy $w$ aglomeracji poznańskiej i województwie wielkopolskim w 2016 roku, „Prace Komisji Geografii Komunikacji PTG” 2019, nr22 (4), s.75-94.https://doi.org/Io.4467/2543859XPKG.I9.022.II543

Cegielski J., Problemy dojazdów do pracy. Próba syntezy, Warszawa 1977.

Dojazdy do pracy. Narodowy Spis Powszechny Ludności i Mieszkań 20II, Główny Urząd Statystyczny, Warszawa 2014.

Dolny E., Społeczno-ekonomiczne problemy dojazdów do pracy, Toruń 1983.

Dzieciuchowicz J.Z., Rozkłady przestrzenne dojazdów do pracy ludności wielkiego miasta (na przykładzie Łodzi), „Studia KPZK” I979, t. 66.

Gawryszewski A., Przestrzenna ruchliwość ludności Polski 1952-1985, Prace habilitacyjne IGiPZ PAN, Warszawa 1989.

Guzik R., Dojazdy do pracy w województwie małopolskim 2006-20II, Kraków 20I5.

Guzik R., Kołoś A., Fiedeń Ł., Kocaj A., Wiedermann K., Dostępność komunikacyjna $i$ relacje przestrzenne $w$ województwie pomorskim, Kraków 2020.

Hebel K., Podróże obligatoryjne mieszkańców polskich miast na przykładzie Gdyni, „Zeszyty Naukowe Uniwersytetu Gdańskiego. Ekonomika Transportu i Logistyka” 20I4, nr 52, s. I29-I45.

Herma J., Dojazdy do pracy w Polsce Południowej (województwo katowickie, kieleckie, krakowskie, opolskie, rzeszowskie) I958-I96I, Kraków 1966.

Jagielski A., Niektóre przestrzenne aspekty dojazdów do pracy, „Przegląd Geograficzny" i969, t. 4I, s. 65I-672.

Kitowski J., Rola dojazdów do pracy w gospodarce narodowej, Lublin 1988.

Komornicki T., Przemiany mobilności codziennej Polaków na tle rozwoju motoryzacji, „Prace Geograficzne” 20II, t. 227.

Kruszka K. (red.), Dojazdy do pracy w Polsce. Terytorialna identyfikacja przepływów ludności związanych z zatrudnieniem, Poznań 2010. 
Krysiak K., Wplywinwestycji i usług turystycznych na rozwój przedsiębiorczości w gminie Uniejów, „Biuletyn Uniejowski” 2019, t. 8, s. 99-II4. https:// doi.org/I0.18778/2299-8403.08.06

Kurek S., Wójtowicz M., Gałka J., Powiązania funkcjonalno-przestrzenne w Krakowskim Obszarze Metropolitalnym w świetle dojazdów do pracy, „Studia Miejskie” 20I5, nr I8, s. 7I-84. https://doi.org/I0.25167/sm.2435

Kurzyk P., Kowalski M., Popularność Uniejowa na tle matych miast regionu łódzkiego oraz konkurujących z nim uzdrowisk, „Biuletyn Uniejowski” 2019, t. 8, s. 77-97. https://doi.org/I0.18778/2299-8403.08.05

Lamprecht M., Kilka uwag o rozwoju Uniejowa w swietle nowych funkcji miasta, „Biuletyn Uniejowski” 20I2, t. I, s. I3I-I4O.

Marciniak K., Dojazdy do pracy $i$ ich uwarunkowania na terenach wiejskich powiatu kutnowskiego, rozprawa doktorska, Uniwersytet Łódzki, Łódź 2019. Matykowski R., Tobolska A., Funkcjonowanie zakładów przemystowych XXI wieku na przyktadzie Swedwood Poland i Volkswagen Motor Polska Sp. z o.o. Analiza dojazdów do pracy, „Prace Komisji Geografii Przemysłu” 2009, nr I4, s. 65-75. https://doi.org/I0.24917/20801653.I4.8

Mortimer-Szymczak H., Uwagi w sprawie dojazdów do pracy, „Łódzkie Czasopismo Gospodarcze" 196I, nr 9, s. 2I-36.

Namysłowski J., Główne ośrodki codziennych dojazdów i wyjazdów w Polsce, Uniwersytet Mikołaja Kopernika, Toruń 1980.

Olędzki M., Dojazdy do pracy. Zagadnienia społeczno-ekonomiczne na przyktadzie rejonu płockiego, Warszawa 1967.

Panecka-Niepsuj M., Przestrzenne zróżnicowanie miast średniej wielkości $w$ Polsce wg dojazdów do pracy, „Annales Universitatis Paedagogicae Cracoviensis. Studia Geographica” 2015, nr 9, s. 83-95.

Przeptywy ludności związane z zatrudnieniem w 2016 r., Główny Urząd Statystyczny, Warszawa 2019.

Rosik P., Komornicki T., Goliszek S., Śleszyński P., Szarata A., Szejgiec-Kolenda B., Pomianowski W., Kowalczyk K., Kompleksowe modelowanie osobowego ruchu drogowego $w$ Polsce. Uwarunkowania na poziomie gminnym, „Prace Geograficzne” 2018, t. 267.

Rosik P., Stępniak M., Wiśniewski R., Dojazdy do pracy do Warszawy $i$ Biategostoku - alternatywne podejścia metodologiczne, "Studia Regionalne i Lokalne" 20I0, nr 2 (40), s. 77-98.

Straszewicz L., Rozmieszczenie miejsc pracy i zamieszkania w Łódzkim Okręgu Przemystowym, „Przegląd Geograficzny” 1956, t. 28, z. 4, s. 775-794. 
Wiśniewski R., Codzienne dojazdy do pracy - metodyczne aspekty badania wielkości i struktury dojazdów na przyktadzie Biategostoku, „Studia Regionalne i Lokalne” 20I2, nr 3 (49), s. 50-64.

Wiśniewski R., Społeczno-demograficzne uwarunkowania dojazdów do pracy do Biategostoku, „Prace Geograficzne” 2013, t. 244.

\section{Źródła internetowe}

http://www.gugik.gov.pl/pzgik/dane-bez-oplat/dane-z-panstwowegorejestru-granic-i-powierzchni-jed nostek-podzialow-tery torialnychkraju-prg [dostęp: 15.04.2021]. https://bdl.stat.gov.pl/BDL/dane/teryt/tablica [dostęp: 15.04.2021]. https://stat.gov.pl/ [dostęp: 15.04.202I]. https://stat.gov.pl/cps/rde/xbcr/poznan/ASSETS_Dojazdy_do_pracy_ metodologia_do_internetu.pdf [dostęp: 15.04.2021]. https://stat.gov.pl/statystyki-eksperymentalne/obszary-funkcjonalne-orazdostepnosc-terytorialna/oszacowanie-odleglosci-i-czasu-przejazdupomiedzy-wybranymi-gminami-w-polsce-w-20I6-roku,II,I.html [dostęp: 15.04.2021].

\section{Population flows connected with employment - the case of Uniejów municipality}

SUMMARY | Commuting to work is the most important and most easily observable indication of spatial-functional connections between localities, municipalities, districts and other regions. For this reason analysis of commuting patterns is very useful in scientific research as well as at various levels of spatial planning. This article identifies the directions and scale of commuting to work for the urban-rural municipality of Uniejów. On the basis of analysis of data from the Central Statistical Office concerning population movements connected with employment in the years 2006, $201 \mathrm{I}$ and 2016 (flows of more than 9 persons)it has been found that the number of out-commutes to work from this municipality as well as incoming travels to work from outside Uniejów municipality have increased.

KEYWO R D S | commuting to work, Uniejów municipality, population flows | Informacje o artykule: przyjęto - 30 kwietnia 202I; zaakceptowano-7 czerwca 202I 